\title{
Termal Uzaktan Algılama Görüntüleri İle Yüzey Sıcaklıklarının Belirlenmesi: Kocaeli Örneği
}

\author{
Özer Akyürek ${ }^{1, *}$ \\ ${ }^{1}$ Kocaeli Üniversitesi, Mühendislik Fakültesi, Harita Mühendisliği Bölümü, 41001, Kocaeli. \\ Özet
}

Kentleşme ile paralel olarak yoğun yerleşim alanlarında sıcaklık, kent çevresinde bulunan kırsal alanlardan daha yüksek olarak gözlenir. Kentsel alanların etrafinda bulunan doğal alanlardan daha sicak olmasina sebep olan bu sicaklik olayı kentsel isı adası olarak tanımlanmaktadır. Uzaktan algılama platformlarında termal bandların kullanılması ile birlikte yer yüzey sicaklıklarının (YYS) belirlenmesi ve ilgili parametrelerin konumsal dağılımları eski yöntemlere göre daha iyi bir biçimde temsil edilmeye başlanmıştır. Uydular sayesinde algılanan görüntülerden elde edilen bu verilerin, düşük maliyetli olması ve geniş alanları kapsamasından dolayı çok çeşitli uygulamalarda veri kaynağı olarak kullanılmalarına imkân sağlamıştır. Bu çalışmada, 2015 - 2019 yılları arasında her yılın Temmuz ayına ait toplam 5 adet Landsat 8 uydu görüntüsünün termal bandı kullanılarak, Kocaeli il sinırları içerisindeki YYS haritaları oluşturulmuştur. Oluşturulan haritalara göre 5 yıllık dönem içerisinde, ilin batı-sanayileşmenin yüksek olduğu-ve güney -jeotermal aktivitenin yüksek olduğu- bölgelerinin YYS değerlerinin yüksek olduğu belirlenmiştir. Ayrica İmit ve Kartepe ilçelerindeki çeşitli sanayi tesislerinin de YYS değerlerinin yüksek olduğu tespit edilmiştir. Hava kalitesi istasyonlarından alınan rüzgâr hızı ve yönü bilgileri ile rüzgâr haritaları oluşturulmuş ve YYS'yi azaltıcı bir etki göstermediği tespit edilmiştir. Son olarak, uydu görüntüleri üzerinden Düzeltilmiş Toprak Bitki İndeksi (SAVI) ve Normalleştirilmiş Fark Yerleşim Alanı İndeksi (NDBI) görüntüleri oluşturularak YYS ile aralarında bulunan istatistiksel ilişki incelenmiştir. Bu inceleme sonucunda SAVI ile ters, NDBI ile doğrusal bir iliş̧kinin olduğu belirlenmiştir.

$\underline{\text { Anahtar Sözcükler }}$

Yer Yüzey Sicaklığı, Landsat 8 TIRS, İstatistiksel Analiz

\section{Determination of Land Surface Temperature with Thermal Remote Sensing Images: A Case Study Kocaeli Province}

\begin{abstract}
In parallel with urbanization, the temperature in dense residential areas is higher than in rural areas around the city. This heat event, which causes the weather to be warmer than the natural areas around urban areas, is defined as the urban heat island. With the use of thermal bands in remote sensing platforms, the determination of land surface temperatures (LST) and spatial distributions of related parameters have started to be represented better than the old methods. The information obtained from the remote sensing platforms, because of the low cost and wide area coverage has been used as data source in various applications. In this study, in Kocaeli province maps of LST were created by using thermal bands of 5 Landsat 8 satellite images taken between July 2015 - 2019. According to the created maps, the LST values of the western - high industrial zone - and southern - geothermal activity - regions of the province were found to be high during the 5-year time period. In addition, various industrial facilities in Izmit and Kartepe districts were determined to have high LST values. Wind maps were created with wind speed and direction data from air quality stations, and it was found that they did not have any reducing effect on the LST. Finally, the Soil Adjusted Vegetation Index (SAVI) and Normalized Difference Built-up Index (NDBI) images were created from the satellite images and the statistical relationship between LST was investigated. As a result of this investigation, it was determined that there is an inverse with SAVI and a linear relationship with $N D B I$.
\end{abstract}

$\underline{\text { Keywords }}$

Land Surface Temperature, Landsat 8 TIRS, Statistical Analysis

\section{Giriş}

Kentleşme ile paralel olarak yoğun yerleşim alanlarında sıcaklık, kent çevresinde bulunan kırsal alanlardan daha yüksek olarak gözlenir. Binaları oluşturan malzemeler, asfalt ve beton yollar, çatı malzemeleri ile kaldırımlar, diğer doğal yüzeylere göre güneşten daha fazla enerji emerek hapsederler. 
Kentsel yerleşim bölgelerinin, çevresinde bulunan doğal alanlardan daha yüksek sıcaklığa sahip olması olayı; kentsel ısı adası olarak tanımlanmaktadır (Oke 1982; Gerçek ve Bayraktar 2014). Şehirlerin düşey yöndeki gelişimi, yeryüzüne ulaşan enerjinin depolanma miktarını arttırarak kent kanyonları oluşturmakta ve kent 1Sı adası etkisini büyütmektedir. Oluşan bu kent kanyonları sebebiyle şehirler, çevrelerine göre farklı iklim özellikleri göstermektedirler (Yılmaz 2015).

Yer yüzey sıcaklığı (YYS) dünya yüzeyi tarafından yayılan sicaklıktır. Bu sıcaklığın temel kaynağı güneştir. Güneşten yeryüzüne ulaşan 1şık enerjisi 1sı enerjisine dönüşerek cisimleri 1sıtır. Kentleşme ve yapılaşmada kullanılan materyaller yeryüzüne ulaşan enerjiyi geri yansıtmayarak absorbe etmekte ve dolayısıyla YYS'nin artmasına sebep olmaktadır. YYS, yeryüzünde çeşitli türdeki olaylara etkisi olan önemli bir faktör olarak gösterilmektedir. YYS verileri bitki değişim analizi, arazi kullanımı ve arazi örtüsü değişimi analizlerinde, küresel ısınma çalışmalarında ve meteorolojik çalışmalarda sıklıkla tercih edilen bir veri türüdür (Parker ve Warner 1973; Zhang vd. 2006; Li vd. 2013; Ndossi ve Avdan 2016; Y1ldiz vd. 2017).

Uzaktan algılama platformlarında termal görüntülerin kullanılması ile birlikte yüzey sıcaklıklarının belirlenmesi ve ilgili parametrelerin konumsal dağılımları daha iyi bir biçimde temsil edilmeye başlanmıştır. Uydular sayesinde algılanan görüntülerden elde edilen verilerin, düşük maliyetli olması ve geniş alanları kapsamasından dolayı çeşitli uygulamalarda veri kaynağı olarak kullanılmalarına olanak sağlamıştır. Landsat 8 uzaktan algılama platformu 2013 yılında uzaya gönderilen ve Ulusal Havacılık ve Uzay Dairesinin (NASA) en uzun havacılık programlarından birisi olan Landsat programının sonuncu elemanıdır. Bünyesinde bulundurduğu dokuz adet spektral ve iki adet termal band ile kullanıcılara veri sağlamaktadır.

Literatürde uzaktan algılama görüntüleri ile YYS'lerin belirlendiği birçok çalışma mevcuttur. Weng vd. (2004) çalışmalarında YYS ile bitki indeksi arasındaki ilişkiyi araştırmışlardır. Uydu görüntüsünü üç kısma ayırarak (yeşil bitki, kuru toprak ve gölge) bu kısımların YYS ile olan korelasyonu incelenmiştir. Chen vd. (2006) çalışmalarında YYS ile arazi örtüsü değişimi arasındaki ilişkinin analizini yapabilmek amacıyla uydu görüntüsünden elde ettikleri indeksler ile YYS arasındaki ilişkiyi belirlemek için çeşitli yaklaşımlar geliştirmişlerdir. Yüksel ve Yılmaz (2008) Ankara'da yapılaşmanın artması sonucunda meydana gelen kentsel 1sı adalarının değişimlerini tespit etmişlerdir. Ayrıca kent içerisinde belirlenen üç farklı arazi örtüsüne ait bölgede yer yüzey sıcaklıkları ile yapılan meteorolojik parametre (sıcaklık, nem) ölçümleri karşılaştırılmış ve bu parametrelerin birbirleriyle olan ilişkileri ortaya koyulmuştur. Prata vd. (2009) YYS'yi elde etmek için kullanılan algoritmaları açıklayan kapsamlı bir çalışma gerçekleştirmişlerdir. Li vd. (2013) YYS elde etmek için uzaktan algılama görüntülerinin termal bandlarını kullanan algoritmaların mevcut durumlarını açıklayan kapsamlı bir araştırma yapmışlardır. Çalışmada algoritmaların teorik altyapıları açıklanarak, yöntemlerin nasıl YYS elde ettikleri gösterilmiştir. Gerçek ve Bayraktar (2014) İzmit kenti için gece ve gündüz uzaktan algılama görüntüleri ile kentsel 1sı adası etkisini inceleyerek karşılaştırmışlardır. YYS'ye kent formunun, kentsel yerleşim dokusunun ve bina yerleşiminin etkileri araştırılmıştır. Y1lmaz (2015) uzaktan algılama görüntüleri ile Adana şehrine ait yüzey 1sı adalarını belirleyerek uydu görüntülerinden oluşturulan arazi örtüsüne göre yüzey sıcaklıkları farklarını belirlemiştir. Ayrıca şehrin yerleşim yeri ve çevresi arasındaki yüzey sıcaklık farkları belirlenerek yıl içerisinde her iki bölgenin gösterdiği farklllıklar analiz edilmiştir. Avdan ve Javanovska (2016) Landsat 8 termal görüntülerini kullanarak yüzey sıcaklığını belirleyebilen bir analiz modülü geliştirmişlerdir. Bu modülde kullanılan yöntem ve algoritmaların yüzey sıcaklığını doğru bir şekilde belirleyebildiği meteorolojik istasyonlardan elde edilen yer yüzey sıcaklıkları ve hava sıcaklıkları ile kontrol edilerek karşılaştırılmıştır. Ndossi ve Avdan (2016) çalışmalarında açık kaynak kodlu bir CBS yazılımı olan QGIS programına Landsat 8 uzaktan algılama platformunun bandlarını kullanarak yer yüzey sıcaklıklarının elde edilerek, haritalandırılmasını sağlayan Python programlama dilinde bir eklenti yazılımı geliştirmişlerdir. Bu eklenti ile disiplinler arası çalışmalarda kullanılabilecek düzeyde yer yüzey sıcaklıkları elde edilmiştir. Oğuz (2016) Kahramanmaraş ili için radyatif transfer eşitliği yöntemiyle ArcGIS Model Builder yazılımında uydu görüntülerinden YYS elde eden bir model tasarlamıştır. Uydu görüntüsünün bandları yardımıyla otomatik olarak YYS değerlerini gösteren sonuç görüntüsünü elde eden bir model geliştirilmiştir. Erener ve Sarp (2017) kentleşmenin 1sı adası oluşumu üzerindeki konumsal etkilerini uydu görüntüleri ile incelemişlerdir. Çalışmada Landsat8 ve Sentinel-2 uydu görüntüleri kullanılarak, bitkisel alanlar için NDVI, kentsel alanlar için ise normalleştirilmiş bina fark indeksi (NDBI) değerleri elde edilerek analizler yapılmıştır. Yıldız vd. (2017) Landsat 8 uzaktan algılama platformunun termal bandlarını kullanarak Afyonkarahisar Gazlıgöl bölgesi ve etrafındaki jeotermal saha potansiyellerini araştırmışlardır. Bölgenin uydu görüntülerinden oluşturulan çizgisellik ve yüzey sıcaklık haritaları karşılaştırılarak potansiyel jeotermal sahaların belirlenmesine çalışılmıştır. Şensoy vd. (2017) Antalya şehrinin şehir 1sı adalarını ve yüzey 1sı adalarını belirlemeye çalışmışlardır. Özellikle son dönemlerde şehrin yüzey ısı adası davranışının yıl içerisinde hangi karakterde olduğu tespit edilmiştir. Balçık ve Ergene (2017) uydu görüntülerinden belirlenen yer yüzey sıcaklıkları ile doğal olmayan alanlar arasındaki istatistiksel ilişkiyi belirlemişlerdir. Landsat 8 termal uzaktan algılama görüntüleri kullanılarak split-window algoritması ile yer yüzey sıcaklıkları elde edilmiş ve çeşitli görüntü indeksleri yardımıyla belirlenen yapay yüzeyler ile YYS arasındaki istatistiksel ilişkiyi ortaya çıkarılmıştır. Jeevalakshmi vd. (2017) Hindistan'ın Chittoor bölgesinde YYS'nin belirlenmesi için çalışmışlardır. Bunun için NDVI indeksinden elde edilen yayınırlık ve arazi örtüsü değerleri kullanılarak elde edilen YYS'nin doğruluğunun arttırılması amaçlanmıştır. Anandababu vd. (2018) çalışmalarında Landsat 8 uydu görüntüsü ile YYS sıcaklıklarının nasıl elde edildiğini göstermişlerdir. Erener ve Sarp (2018) Kocaeli bölgesinde sanayi alanlarının zamansal ve konumsal dağılımındaki değişimin yer yüzey sıcaklığına etkisini araştırmışlardır. 
Landsat 7 ETM+ ve 8 OLI verileri kullanılarak yaklaşık 14 yıllık dönem için bölgedeki sanayi alanlarının zamansal ve konumsal yayılımı ve değişimi belirlenerek, 16 yıllık periyot için yer yüzey sıcaklığı değişimi ile korelasyonu incelenmiştir. Fils vd. (2018) Douala şehri çalışmalarında yerleşim alanlarının YYS'ye yaptığı etkiyi araştırmışlardır. Zamansal olarak artan yapılaşmanın YYS' nin artışına yaptığı pozitif etki ortaya koyulmuştur. Şekertekin ve Marangoz (2019) Zonguldak şehir merkezi için uydu görüntülerinden elde ettikleri arazi kullanım örtüsü ile yer yüzey sıcaklıkları arasındaki ilişkiyi araştırmışlardır. Taşdelen (2019) hazırladığı yüksek lisans tezi çalışmasında MODIS uydu görüntülerini kullanarak Türkiye ölçeğinde yaptığı çalışmada 2000, 2005, 2010 ve 2017 yılları için YYS haritalarını üretip, zamansal olarak değişimlerini incelemiştir. Yerel ölçekte ise yine aynı yıllardaki Landsat 5/8 uydu görüntülerini kullanılarak Kocaeli il sınırları içerisinde YYS haritaları oluşturularak toprak, su, şehir, bitki gibi farklı arazi kullanım alanlarına ait sıcaklık değerleri karşılaştırılmıştır.

Çalışmanın genel amacı; Kocaeli ilinin YYS değerlerinin zamansal olarak analiz edilip, çevresel ve yapay etkilerle olan ilişkisini araştırmaktır. Ayrıca il genelinde bulunan Hava Kalitesi istasyonlarından elde edilen rüzgar yönü ve hızı bilgilerinden, rüzgar haritaları oluşturulup YYS'ye yaptığı etki araştırılmıştır. Son olarak ise Düzeltilmiş Toprak Bitki İndeksi (The Soil-Adjusted Vegetetaion Index (SAVI)) ve Normalleştirilmiş Fark Yerleşim Alanı İndeksi (The Normalized Difference Built-Up Index (NDBI)) ile yer yüzey sıcaklığı arasındaki ilişki araştırılarak, bu iki indeks ile YYS arasında korelasyon olup olmadığı belirlenmeye çalışılmıştır.

\section{2. Çalışma Alanı ve Özellikleri}

Kocaeli İli $29^{\circ} 22^{\prime}-30^{\circ} 21^{\prime}$ D, 40 $40^{\circ} 31^{\prime}-41^{\circ} 13^{\prime} \mathrm{K}$ coğrafi koordinatlarında konumlanmış, Sakarya, Bursa, İstanbul ve Yalova illeri ile komşu, $3.623 \mathrm{~km}^{2}$ lik yüz ölçüme sahip bir sanayi şehridir (Şekil 1). TüİK verilerine göre 2018 y1lında 1.906 .391 kişilik bir nüfusa ve kilometrekareye 526 kişilik bir nüfus yoğunluğuna sahip Marmara Bölgesi'nin üçüncü büyük şehridir. Kocaeli ilinin nüfusu 2008 yılından itibaren değişen hızlarda sürekli olarak artarak \%26 oranında bir artış göstermiştir. Bu artışa bağlı olarak km²'ye düşen insan sayısı 2007 yılından itibaren artan bir trend göstermektedir (Şekil 2). Bu trende bağlı olarak da yapılaşmış alanların artarak genişlediği, kentleşmenin arttığı, şehir ve sanayi alanlarının büyüdüğü sonucuna ulaşılmaktadır.

Kocaeli ilinde İzmit körfezi ile Karadeniz’e kıyısı olan bölgelerde 1lıman, dağlık bölgelerde ise daha sert bir iklim görülmektedir. Kocaeli’nin, Akdeniz ile Karadeniz iklimleri arasında bir iklime sahip olduğundan bahsedilebilir. Öztürk vd. (2017) yaptıkları Köppen-Geiger iklim sınıflandırmasında Kocaeli ilini Csa olarak sınıflamışlardır. Köppen-Geiger sınıflandırmasına göre Csa sınıfı; ılıman ya da kışları ılıman nemli orta enlem sınıfında, yazları kurak ve sıcak geçen olarak sınıflandırılmıştır. Kocaeli il merkezinde yaz mevsimi sıcak ve az yağışlı, kış mevsimi ise yă̆ışlı, zaman zaman karlı ve soğuk geçmektedir. Kocaeli’de yaz mevsiminde körfez kıyılarında zaman zaman bunaltıcı sıcaklar görülürken Karadeniz kıyıları daha serin geçmektedir. Yıllık ortalama yağış miktarı bölgesel değişkenlikler göstermektedir. Karadeniz kıyılarında 1000 mm'yi aşarken, bu miktar güneye doğru inildikçe azalmakta ve İzmit merkezde 800 mm'nin altına düşmektedir. Kocaeli’de rüzgarlar kış mevsiminde kuzey ve kuzeydoğudan, yaz mevsiminde ise kuzeydoğudan esmektedir (URL-1 2017).

Kocaeli'deki bitki örtüsü, genel olarak Marmara Bölgesi’nin özelliklerini taşır. Kıyı kesimler ile dağlık alanlarda önemli çeşitlilikler göze çarpar. Ayrıca güneye doğru inildikçe Karadeniz'e özgü bitki toplulukları yerini Akdeniz bitkilerine bırakır. Karadeniz kıyısı ile Samanlı Dağları arasında kalan bölgelerde sık ormanlar görülür. Bu ormanlarda yaygın olarak kayın ağaçları bulunur. Çeşitli bölgelerde kayın ağaçlarına kestane, meşe ve gürgen ağaçları da eklenir. Samanlı Dağları'nın yüksek kesimlerinde genellikle iğne yapraklı ağaçlar bulunur. Körfezin kuzey ve doğu kesiminde Akdeniz iklimi makilikleri görülür. Körfezin kuzey kıyılarında eskiden yaygın olan zeytinlikler, kent ve sanayi alanı yaratılması amacıyla yok edilmiş durumdadır. Tahrip edilen alanlar step bitkileri ve yalancı makilerle kaplanmıştır (URL-1 2017).

Kocaeli ilinin sıcaklık değerleri incelendiğinde ise en soğuk ayın Ocak, en sıcak ayın ise Temmuz ayı olduğu görülmektedir (Tablo 1). Kış mevsiminde (Aralık, Ocak ve Şubat) ortalama sıcaklık $7.1{ }^{\circ} \mathrm{C}$ iken yaz mevsiminde (Haziran, Temmuz ve Ağustos) ortalama sıcaklık $23.2{ }^{\circ} \mathrm{C}$ dir. Ölçüm periyodu olan 1929 - 2018 yılları arasında Meteoroloji Genel Müdürlüğünden elde edilen Tablo 1 verilerine göre ortalama sıcaklık değeri en yüksek olan ay Temmuz ayıdır. Ayrıca ortalama güneşlenme süreleri de incelendiğinde gün içerisinde 9.6 saat ile Temmuz ayının en yüksek, 2.5 saat ile Ocak ayı ise en düşük değere sahip olduğu görülmektedir. Tablo 1'de gösterilen 13 Temmuz 2000 tarihinde ölçülen $44.1{ }^{\circ} \mathrm{C}$ ve 09 Şubat 1929 tarihinde ölçülen $-18.0{ }^{\circ} \mathrm{C}$ ölçüm periyodu içerisinde belirlenen sırasıyla en yüksek ve en düşük değerlerdir. 


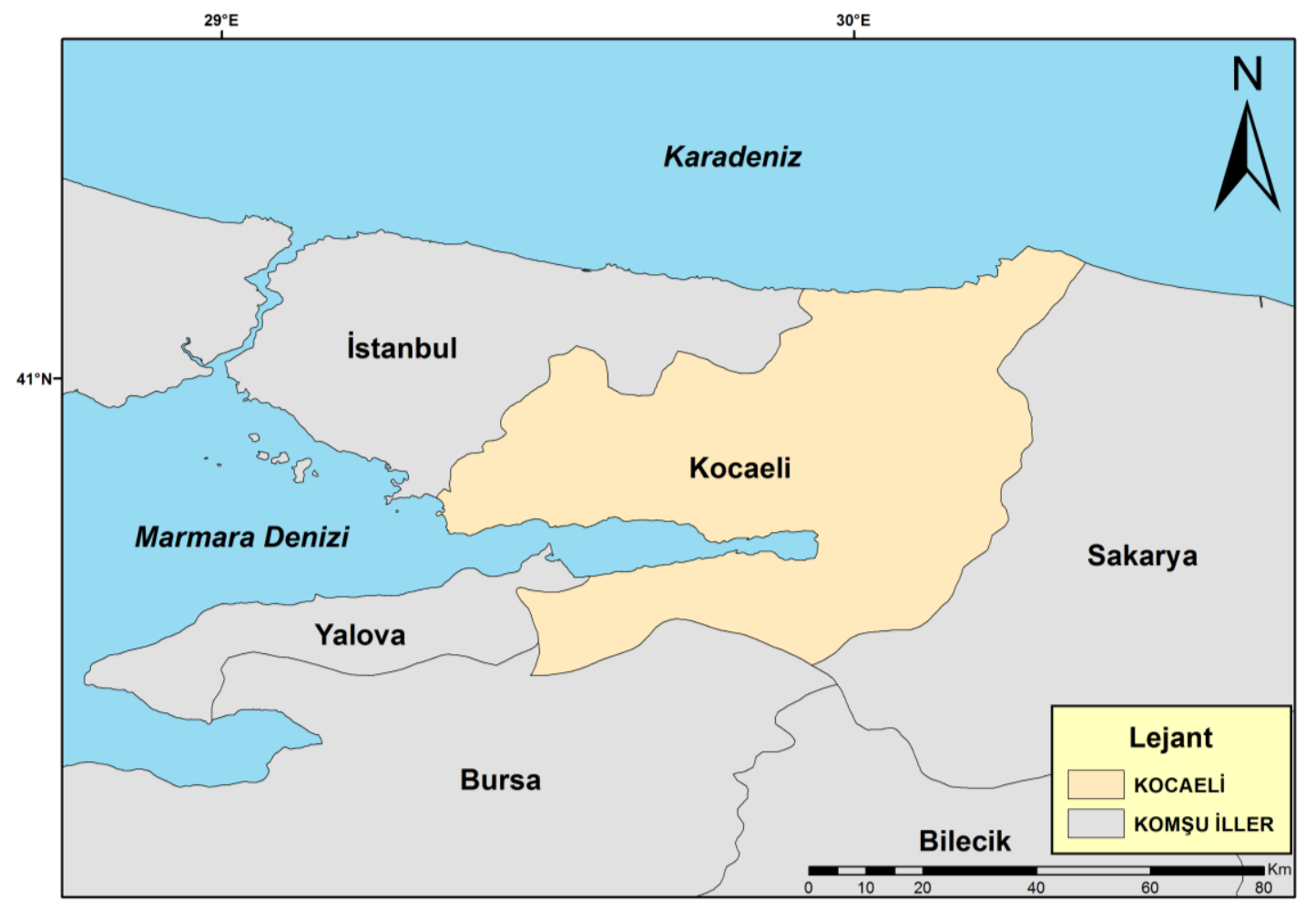

Şekil 1: Kocaeli ili ve çevresinin genel görünümü
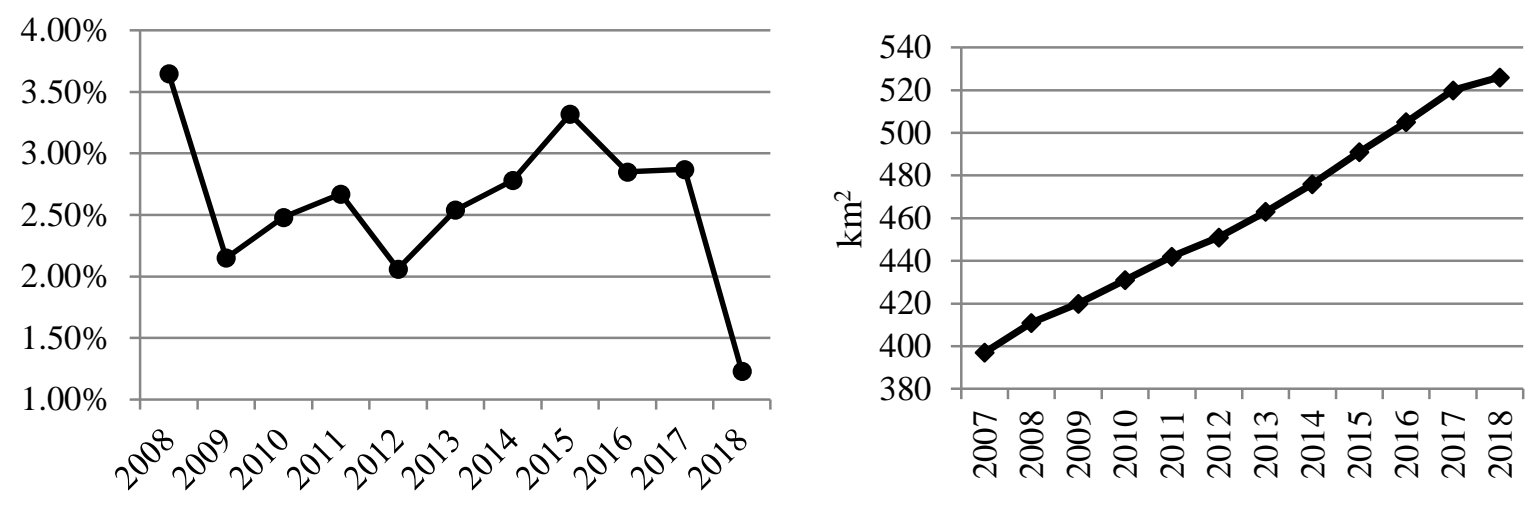

Şekil 2: Kocaeli ilinin yıllara göre nüfus artış hızı (solda) ve nüfus yoğunluğu (km² ye düşen kişi sayısı)(sağda)(URL-2 2019)

Tablo 1: Kocaeli iline ait meteorolojik verilerin genel istatistik değerleri (Ölçüm Periyodu: 1929-2018) (URL-3 2019)

\begin{tabular}{ccccccc}
\hline & $\begin{array}{c}\text { Ortalama } \\
\text { Sicaklık }\left({ }^{\circ} \mathbf{C}\right)\end{array}$ & $\begin{array}{c}\text { Ortalama } \\
\text { En Yüksek } \\
\text { Sıcaklık }\left({ }^{\circ} \mathbf{C}\right)\end{array}$ & $\begin{array}{c}\text { Ortalama } \\
\text { En Düşük } \\
\text { Sıcaklık }\left({ }^{\circ} \mathbf{C}\right)\end{array}$ & $\begin{array}{c}\text { Ortalama } \\
\text { Güneşlenme } \\
\text { Süresi }(\text { saat })\end{array}$ & $\begin{array}{c}\text { En Yüksek } \\
\text { Sıcaklık }\left({ }^{\circ} \mathbf{C}\right)\end{array}$ & $\begin{array}{c}\text { En Düşük } \\
\text { Sıcaklık }\left({ }^{\circ} \mathbf{C}\right)\end{array}$ \\
\hline Ocak & 6.2 & 9.6 & 3.1 & 2.5 & 24.9 & -13.1 \\
Şubat & 6.9 & 10.5 & 3.4 & 3.0 & 26.7 & -18.0 \\
Mart & 8.8 & 13.2 & 4.8 & 4.0 & 30.8 & -6.5 \\
Nisan & 13.2 & 18.5 & 8.5 & 5.7 & 35.0 & -1.0 \\
Mayıs & 17.7 & 23.3 & 12.8 & 7.3 & 37.2 & 1.8 \\
Haziran & 21.9 & 27.4 & 16.5 & 8.9 & 40.7 & 4.0 \\
Temmuz & 23.9 & 29.5 & 18.9 & 9.6 & 44.1 & 10.1 \\
Ăgustos & 23.8 & 29.7 & 19.1 & 9.1 & 42.9 & 10.9 \\
Eylül & 20.4 & 26.1 & 15.9 & 7.1 & 40.2 & 4.9 \\
Ekim & 16.1 & 20.9 & 12.4 & 4.8 & 36.2 & 2.4 \\
Kasım & 12.0 & 16.4 & 8.6 & 3.6 & 29.1 & -3.4 \\
Aralık & 8.3 & 11.7 & 5.3 & 2.6 & 26.0 & -8.8 \\
Yıllık & 14.9 & 19.7 & 10.8 & 68.2 & & \\
\hline
\end{tabular}




\section{Yöntem}

Yer yüzey sıcaklığını belirlemede en yaygın olarak kullanılan uzaktan algılama platformu NASA'nın yürütücülüğünde bulunan Landsat 8 uydusudur. Landsat 8, 2013 yılında uzaya gönderilen ve Landsat programının en son ürünüdür. Landsat 8 platformu $705 \mathrm{~km}$ yükseklikte, 16 günlük zamansal çözünürlüğe ve dünyanın çevresini 98.9 dakikada dönebilen güneş ile senkronize bir yörüngeye sahiptir. Landsat 8 platformu bünyesinde iki farklı algılayıc1 sistemi barındırmaktadır. Bunlardan ilki Operasyonel Yer Görüntüleyicisi (OLI) dir. OLI sistemi daha önceki Landsat algılayıcılarının içerdiği bandlara ek olarak kıyı/aerosol uygulamaları için derin mavi (Band 1), sirrus bulutlarının analiz ve tespiti için kısa dalga kızılötesi (Band 9) ve band kalite değerlendirmesi amacını taşıyan 3 yeni banda sahiptir. İkinci algılayıcı sistem ise Termal Kızılötesi Sensör (TIRS) dür. TIRS sistemi bünyesinde $100 \mathrm{~m}$ konumsal (30 m yeniden örnekleme), 16 bit radyometrik çözünürlük, 10.6 - $12.51 \mu \mathrm{m}$ 'lik elektromanyetik spektrum termal dalga boyunda iki adet band bulundurmaktadır. Landsat 8 (OLI\&TIRS) algılayıcısı, Landsat 7 ETM+ ve Landsat 5 TM algılayıcılarına göre daha dar spektral band genişliğine ve daha güçlü sinyal gürültü karakteristiğine sahiptir (USGS 2019).

Yeryüzü üzerinde geniş alanlarda yüzey sıcaklıklarının belirlenmesi için nokta bazlı yapılan lokal ölçümler ile çalışma alanındaki sıcaklık değerleri tam olarak temsil edilememektedir. Uzaktan algılama uyduları sayesinde, dünya yüzeyi üzerinde yüksek çözünürlüklü sıcaklık verilerini belirlemek mümkün hale gelmiş ve buz kalınlığı, bitki sağlığı, orman yangınları ve jeotermal alanların belirlenmesi gibi çalışma alanlarında kullanılma imkanı bulmuştur (Ndossi ve Avdan 2016).

Tablo 2'de veri seti olarak kullanılmış olan 5 adet Landsat 8 uydu görüntüsünün elde edildiği gün ay ve saat bilgileri gösterilmektedir. Şekil 3 'te Landsat 8 uzaktan algılama platformunun optik ve termal bandları yardımıyla yer yüzeyi sıcaklığının elde edilmesine ilişkin iş akış şeması gösterilmektedir.

Tablo 2: Veri seti olarak kullanılan uydu görüntüleri bilgileri

\begin{tabular}{lll}
\hline & Tarih & Saat \\
\hline 2015 Görüntüsü & 29.07 .2015 & $08: 39$ \\
2016 Görüntüsü & 31.07 .2016 & $08: 39$ \\
2017 Görüntüsü & 02.07 .2017 & $08: 39$ \\
2018 Görüntüsü & 05.07 .2018 & $08: 38$ \\
2019 Görüntüsü & 08.07 .2019 & $08: 39$ \\
\hline
\end{tabular}

\subsection{Piksel Değerlerinin (DN) Sprektral Radyans Değerlerine Dönüştürülmesi}

Yer yüzey sıcaklığını belirlemek için kullanılacak olan termal görüntü bandı değerlerine (DN: Digital Number), uydu görüntüsüne ait metaveri dosyasındaki parametreler yardımıyla spektral radyans değeri dönüşümü uygulanır. Spektral radyans değeri belirli bir dalga boyunda, belirli bir açı ve bölgeden yansıyan veya iletilen enerji miktarı olarak tanımlanmaktadır (Yıldız vd. 2017). Bu dönüşüm için aşağıdaki formül kullanılır;

$\mathrm{L}_{\lambda}=\mathrm{M}_{\mathrm{L}} * \mathrm{Q}_{\mathrm{cal}}+\mathrm{A}_{\mathrm{L}}$

Bu formülde kullanılan;

$\mathrm{L}_{\lambda}=$ Hesaplanan Radyans değeri $(\mathrm{W} /(\mathrm{m} 2 * \mathrm{sr} * \mu \mathrm{m}))$

$\mathrm{M}_{\mathrm{L}}=$ Radyans çarpımsal ölçeklendirme faktörü (Uydu meta verisinden)

$\mathrm{Q}_{\mathrm{cal}}=$ Uydu görüntüsünün piksel değeri (DN)

$\mathrm{A}_{\mathrm{L}}=$ Radyans ilave ölçeklendirme faktörünü (Uydu meta verisinden) temsil etmektedir. 


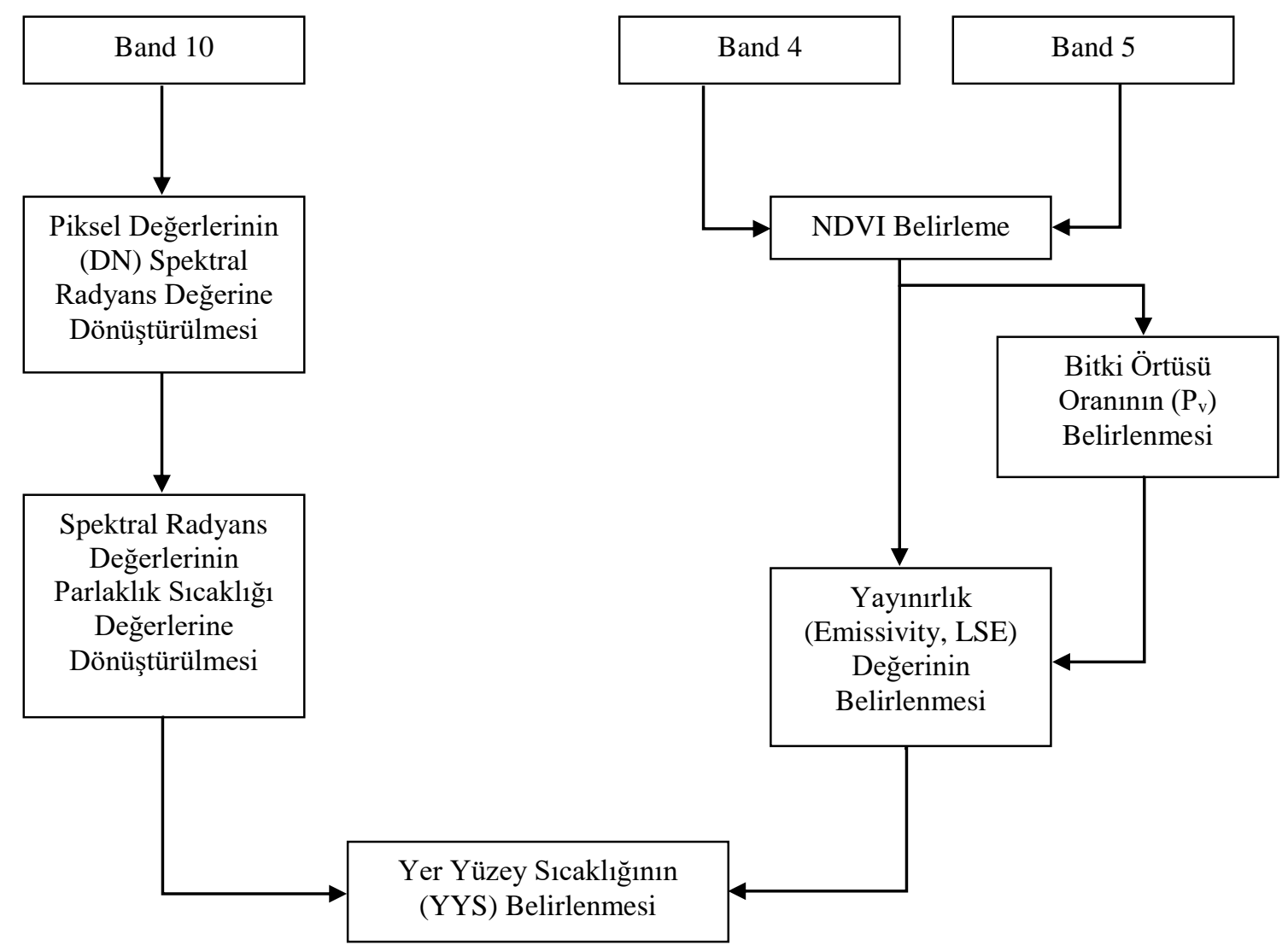

Şekil 3: Yer Yüzey Sıcaklığı belirleme için kullanılan iş akış şeması

\subsection{Sprektral Radyans Değerlerinin Parlaklık Sıcaklığı Değerlerine Dönüştürülmesi}

Parlaklık Sıcaklığı, dünya atmosferinin en yüksek noktasından (T: Parlaklık Sicaklı̆̆ı) yukarıya doğru yol alan mikrodalga yayılımının parlaklık değeridir. İkinci işlem adımı ise Eşitlik (1) ile piksel değerlerinden (DN) elde edilen spektral radyans değerlerini parlaklık sıcaklığına $(\mathrm{T})$ dönüştürmektir. Bu dönüşüm;

$\mathrm{T}=\frac{\mathrm{K}_{2}}{\ln \left(\frac{\mathrm{K}_{1}}{\mathrm{~L}_{\lambda}}+1\right)}-273.15$

formül yardımıyla gerçekleştirilir. Bu formülde bahsedilen;

$\mathrm{T}=$ Parlaklık sıcaklığı $\left(\mathrm{C}^{0}\right)$

$\mathrm{L}_{\lambda}=$ Hesaplanan Radyans değeri $(\mathrm{W} /(\mathrm{m} 2 * \mathrm{sr} * \mu \mathrm{m}))$

$\mathrm{K}_{1}$ ve $\mathrm{K}_{2}=$ Uydu meta verisinde bulunan Termal Band için dönüşüm sabitlerini tanımlamaktadır.

\subsection{Normalize Edilmiş Fark Bitki İndeksinin (NDVI) Belirlenmesi}

Yer yüzey yayınırlık ve Bitki Örtüsü Oranının belirlenebilmesi için Normalize Edilmiş Fark Bitki İndeksinin (NDVI) hesaplanması gerekmektedir. YYS belirlenmesinde, NDVI değerlerinin DN değerlerinden değil yansıtım (reflectance) değerlerinden elde edilmesi gerekmektedir. NDVI değeri yakın kızılötesi ve kırmızı bandlarının yansıtım değerleri kullanılarak aşağıdaki formül yardımıyla hesaplanır;

NDVI $=\frac{\text { Yakın Kızı ötesi }- \text { Kırmızı }}{\text { Yakın Kızıl ötesi }+ \text { Kırmızı }}$

Landsat 8 platformunda 5. band yakın kızılötesi, 4. band ise kırmızı bandı temsil etmektedir. Bu iki bandın Eşitlik 3 ’te gösterilen oranı alınarak bitki örtüsünün durumu tespit edilebilir. 


\subsection{Bitki Örtüsü Oranının (Pv) Belirlenmesi}

Çalışma alanına ait NDVI değerleri belirlendikten sonra NDVI'ın bitki ve toprak değerleri kullanılarak Bitki Örtüsü Oranı $\left(\mathrm{P}_{\mathrm{v}}\right)$ belirlenir. Bu oran NDVI üzerinden maksimum $\left(\mathrm{NDVI}_{\max }\right)$ ve minimum $\left(\mathrm{NDVI}_{\min }\right)$ değerleri kullanılarak belirlenir. Bitki Örtüsü Oranı $\left(\mathrm{P}_{\mathrm{v}}\right)$;

$\mathrm{P}_{\mathrm{v}}=\left(\mathrm{NDVI}-\mathrm{NDVI}_{\min } / \mathrm{NDVI}_{\max }-\mathrm{NDVI}_{\min }\right)^{2}$

formülü yardımıyla hesaplanır (Sobrino vd. 2004). Bu oran yeryüzü yayınırlık (1şınım) değerinin (ع) hesaplanmasında kullanılır.

\subsection{Yayınırlık (Emissivity, LSE) Değerlerinin Belirlenmesi}

Yayınırlık (1şınım) (ع) değeri yer yüzeyi sıcaklıklarının hesaplanmasında kullanılan önemli bir parametredir. Yayınırlık değerini belirlemek için birçok yöntem geliştirilmiştir. Ancak bu çalışmada NDVI değerlerine dayalı yöntem kullanılmıştır. Bu yöntemde NDVI değerleri toprak ve bitki değerleri olarak eşiklenerek çalışma alanına ait yayınırlık değerleri hesaplanmıştır. Eşik değerler olarak literatürde global olarak kullanılmış değerler olan toprak için 0.2, bitki için ise 0.5 değeri kullanılmıştır (Sobrino ve Raissouni 2000). Buna göre $\varepsilon_{\lambda}$;

$\varepsilon_{\lambda}$
$= \begin{cases}\varepsilon_{\mathrm{s} \lambda}, & \mathrm{NDVI}<\mathrm{NDVI}_{\mathrm{s}} \\ \varepsilon_{\mathrm{v} \lambda} \mathrm{P}_{\mathrm{v}}+\varepsilon_{\mathrm{s} \lambda}\left(1-\mathrm{P}_{\mathrm{v}}\right)+\mathrm{C}, & \mathrm{NDVI}_{\mathrm{s}} \leq \mathrm{NDVI} \leq \mathrm{NDVI}_{\mathrm{v}} \\ \varepsilon_{\mathrm{s} \lambda}+\mathrm{C}, & \mathrm{NDVI}>\mathrm{NDVI}_{\mathrm{v}}\end{cases}$

formülleri kullanılarak eşik değerler yardımıyla yayınırlık değerleri hesaplanmıştır. Burada $\varepsilon_{\mathrm{s} \lambda}$ toprak yüzeylerden yayılan enerjiyi, $\varepsilon_{\mathrm{v} \lambda}$ ise bitkilerden yayılan enerji değerini temsil etmektedir. $\mathrm{C}$ değeri yer yüzeyinin pürüzlülüğünü temsil eder. Düz alanlar için sıfır kabul edilir. Bu çalışmada C değeri Sobrino ve Raissouni'nin kabul ettiği sabit değer olan 0.005 olarak kabul edilmiş ve hesaplamalarda bu şekilde kullanılmıştır.

Belirlenen NDVI değerleri sıfırın altında ise bu bölgeler su sınıfı olarak tanımlanıp yayınırlık değeri olarak 0.991 kullanılır. $0<\mathrm{NDVI}<\mathrm{NDVI}_{\mathrm{s}}$ değerleri arasında kalan bölgeler kayaç ve toprak alanlar olarak tanımlanır ve yayınırlık değeri olarak 0.996 kabul edilir. $\mathrm{NDVI}_{\mathrm{s}} \leq \mathrm{NDVI} \leq \mathrm{NDVI}_{\mathrm{v}}$ değerleri arasında kalan bölgeler karışık bitki örtüsü olarak tanımlanır ve yayınırlık değeri Eşitlik 5 'te verilen formül ile hesaplanır. NDVI $>\mathrm{NDVI}_{\mathrm{v}}$ değerleri arasında kalan bölgeler yeşil alanlar olarak tanımlanır ve yayınırlık değeri olarak 0.973 kullanılır.

\subsection{Yer Yüzey Sıcaklığının (YYS) Değerlerinin Belirlenmesi}

Yayınırlık değeri hesaplanarak belirlendikten sonra son olarak yer yüzeyi sıcaklık değeri belirleme aşaması gerçekleştirilir. Bunun için daha önceki adımlarda hesaplanmış olan sensör sıcaklığı değerine yer yüzey yayınırlık düzeltmesi yapılması gerekmektedir. Bu düzeltme için;

$\operatorname{LST}=\frac{\mathrm{T}}{\left(1+\left(\frac{\mathrm{w} \cdot \mathrm{T}}{\rho}\right) * \ln (\varepsilon)\right)}$

formülü kullanılır. Burada daha önceki aşamalarda hesaplanmış olan T sıcaklık değerleri, w kullanılan termal banda ait ortalama dalga boyu değeri $(10.9 \mu \mathrm{m}), \varepsilon$ ise yayınırlık değerini temsil etmektedir. $\rho$ değeri sabit bir değer olup aşağıda belirtilen formül yardımıyla hesaplanmaktadır.

$\rho=\mathrm{h} * \mathrm{c} / \mathrm{s}=1.438 \times 10-2 \mathrm{mK}$

h: Planck sabiti $(6.626 * 10-34 \mathrm{Js})$,

s: Boltzmann sabiti $(1.38 * 10-23 \mathrm{~J} / \mathrm{K})$,

c: Işı1k hızı $(2.998 * 108 \mathrm{~m} / \mathrm{s})$ dır.

\subsection{Uydu Görüntülerinden İndeks Değerlerinin Belirlenmesi}

\subsubsection{Düzeltilmiş toprak bitki indeksi (The soil-adjusted vegetation index (SAVI))}

Uzaktan algılama görüntüleri üzerinden genellikle kırmızı ve yakın kızı̈ötesi bandların birbirlerine oranlanması ile bitki alanlarını belirleyebilmek için çeşitli indeksler oluşturulmuştur. NDVI bunlardan en çok bilinen ve tercih edilen indekstir. Bitki indekslerinde kızılötesi bandın spektral aralığında yüksek bitki yansıtımı ile kırmızı bandın yüksek pigment emilimi değerlerinden faydalanılır. 
Yoğun kentsel dokuya sahip olan şehirlerde SAVI indeksi, yoğunluğu daha az olan bitki örtüsü alanlarını tespit etmek açısından NDVI indeksine göre daha hassas ve doğru sonuçlar vermektedir (Ergene 2016). SAVI'yı belirlemek için;

SAVI $=\frac{\left(\text { Yakın Kızıl ötesi-Kırmızı) }{ }^{*}(1+\mathrm{L})\right.}{(\text { Yakın Kızı ötesi }+ \text { Kırmızı }+\mathrm{L})}$

formülü kullanılır. Buradaki $\mathrm{L}$ değeri bir düzeltme faktörüdür. Bu faktör değeri düşük yoğunlukta 1 , yüksek yoğunlukta 0 kabul edilerek kullanılır. Bu çalışmada $\mathrm{L}$ faktörü Kocaeli ilinin yoğunluğu orta düzeyde olduğundan dolayı 0.5 olarak kabul edilmiştir.

\subsubsection{Normalleştirilmiş fark yerleşim alanı indeksi (The normalized difference built-up index (NDBI))}

Bu indeks uydu görüntülerinden faydalanarak kentsel alanların otomatik olarak belirlenmesi amacıyla 2003 yılında Zha, Gao ve Ni tarafindan geliştirilmiştir. Uydu görüntülerinin farklı bandlarında yerleşim alanlarının özelliklerine göre spektral yansıtım değerlerini bulmak için kullanılmıştır. Kentsel alanlarda düşük yansıtım özelliğine sahip yakın kızılötesi band ile yüksek yansıtım gösteren orta kızı̈ötesi bandların birbirine oranlanması ile oluşturulur (Ergene 2016). NDBI'yı hesaplamak için;

$\mathrm{NDBI}=\frac{(\text { Orta Kızılötesi-Yakın Kızılötesi) }}{(\text { Orta Kızılötesi+Yakın Kızılötesi) }}$

formülü kullanılır.

\section{Bulgular}

Çalışmada veri seti olarak Landsat 8 uzaktan algılama platformu tarafindan 2015 - 2019 yıllarının Temmuz ayında elde edilen 5 adet uzaktan algılama görüntüsünün termal bandı (Band 10) kullanılmıştır. Veri seti olarak Temmuz ayının seçilmesinin sebebi bulutluluk oranının bu mevsimde en az olmasından kaynaklanmaktadır. Çalışmada kullanılan 5 adet uydu görüntüsü ilk olarak ENVI paket programında atmosferik ve radyometrik olarak düzeltilmiştir. Çalışma içerisinde gösterilen yer yüzey sıcaklığı haritalarının, rüzgar yönü haritalarının ve indeks görüntülerinin oluşturulmasında ArcGIS 10.2 yazılımı kullanılmıştır. Ayrıca uydu görüntülerinin radyans ve reflektans dönüşümlerinin yapılması için yine ArcGIS yazılımının "Raster Calculator" modülünden faydalanılmıştır.

Bölüm 3'te açıklanan ve matematik modelleri verilen formüller yardımıyla 5 yıllık periyot için uydu görüntüleri yardımıyla Kocaeli iline ait yer yüzey sıcaklıkları belirlenmiştir. Elde edilen yer yüzey sıcaklıklarına ait istatistiki bilgiler Tablo 3 'te gösterilmiştir.

Tablo 3: Yer yüzey sıcaklıklarının $\left({ }^{\circ} \mathrm{C}\right)$ istatistiki bilgileri

\begin{tabular}{cccccc}
\hline & $\mathbf{2 0 1 5}$ & $\mathbf{2 0 1 6}$ & $\mathbf{2 0 1 7}$ & $\mathbf{2 0 1 8}$ & $\mathbf{2 0 1 9}$ \\
\hline Minimum & 23.56 & 12.16 & 21.45 & 18.18 & 19.84 \\
Maksimum & 48.52 & 49.05 & 53.95 & 46.53 & 48.56 \\
\hline Ortalama & 31.74 & 30.42 & 32.07 & 27.05 & 30.40 \\
\hline
\end{tabular}

Tablo 3 incelendiğinde en düşük değerin $12.16^{\circ} \mathrm{C}$ ile 2016 yllında ve en yüksek değerin ise $53.95^{\circ} \mathrm{C}$ ile 2017 yllında ölçüldüğü görülmektedir. Ortalama sıcaklıklar incelendiğinde de yer yüzey sıcaklığı olarak en sıcak yılın $32.07^{\circ} \mathrm{C}$ ile 2017 yıll, en soğuk yılın ise $27.05^{\circ} \mathrm{C}$ ile 2018 yılının olduğu belirlenmiştir.

Şekil 4'te uydu görüntülerinden elde edilen yer yüzey sıcaklık bilgilerine göre oluşturulan haritalar ve ilçe sınırları gösterilmektedir. Buna göre; Şekil 4-a'da gösterilen 2015 yılına ait olan yer yüzey sıcaklık haritası incelendiğinde Darıca, Çayırova, Gebze, Dilovası ve Karamürsel ilçelerinin yer yüzey sıcaklı̆̆ı bakımından en yüksek alanlar olduğu görülmektedir. Ayrıca İzmit ve Kartepe ilçelerinde belirli noktalarda çok yüksek sıcaklıkların olduğu alanlar görülmektedir. Bu alanlar incelendiğinde koyu renkli çatı yüzeylerine sahip sanayi tesisleri oldukları tespit edilmiştir. Kocaeli ili geneline bakılacak olursa tarım ve yerleşim alanlarının genellikle sıcaklık değeri bakımından yüksek, yeşil alanların ve ormanlık bölgelerin ise sıcaklık değeri olarak düşük değerlere sahip oldukları görülmektedir. Şekil 4-b'de gösterilen 2016 yılına ait haritada en sıcak bölgenin Karamürsel ilçesinin güneyinde kalan alanın ve yine bir önceki yılda olduğu gibi İzmit ve Kartepe ilçelerinde bulunan sanayi tesislerinin olduğu görülmektedir. Ayrıca Dilovası, Gebze, Darıca ve Çayırova ilçelerinin de yüzey sıcaklıkları yine yüksek değerde çıkmıştır. Yüzey sıcaklıklarında yeşil alanların yine düşük sıcaklıklarda olduğu, kentsel, sanayi ve tarım alanlarının ise sıcaklıklarının yüksek değerlerde olduğu görülmektedir. Şekil 4-c'de 2017 yılına ait yüzey sıcaklık haritasında Dilovası, Gebze, Darıca ve Çayırova ilçelerinin bulunduğu sanayi ve kentsel yerleşimin yüksek olduğu ilin batı bölgelerinin yer yüzey sıcaklıkları mevsim normallerinin de üzerinde olduğu tespit edilmiştir. Daha önceki yıllara oranla İzmit körfezi çevresindeki Körfez, Derince, İzmit, Başiskele ve Gölcük ilçelerindeki yer yüzey sıcaklıklarında artış olduğu görülmektedir. 
İzmit ve Kartepe ilçeleri sınırlarındaki sanayi tesislerine ait sıcaklık değerleri yine bu yıl içerisinde de yüksek olarak tespit edilmiştir. Kartepe ilçesinin bulunduğu Samanlı dağlarının ormanlarla kaplı bölgeleri ve Kandıra ilçesinin Karadeniz sahili kıyısında kalan ormanlık alanların yüzey sıcaklıklarının düşük olduğu görülmektedir. Şekil 4-d'de 2018 yılına ait yer yüzey sıcaklık haritasında bir önceki yıla oranla yer yüzey sıcaklıklarında ciddi düşüşün olduğu görülmektedir. Buna rağmen İzmit ve Kartepe ilçeleri içerisindeki sanayi tesislerinin sıcaklıkları yine de yüksek olarak belirlenmiştir. Şekil 4-e'de gösterilen 2019 yılı yer yüzey sıcaklığı haritasında Darıca, Çayırova, Gebze ve Dilovası ilçelerinin yüzey sıcaklıklarının artış gösterdiği, sanayi tesislerinin yüzey sıcaklıklarının diğer yıllarda olduğu gibi yine yüksek değerlerde olduğu görülmektedir.

Yer yüzey sıcaklıkları belirlendikten sonra bu sıcaklık değerlerini etkileyen parametrelerin araştırılması yapılmıştır. Bunun için Kocaeli ili ve çevresinden bulunan 18 adet Marmara Hava Kalitesi İzleme İstasyonunda ölçülen günlük rüzgar hızı ve yönü değerlerinin ortalaması alınarak, çalışma dönemi olan Temmuz ayına ait oluşturulan aylık ortalama değerlerden rüzgar haritaları oluşturulmuştur (Şekil 5).

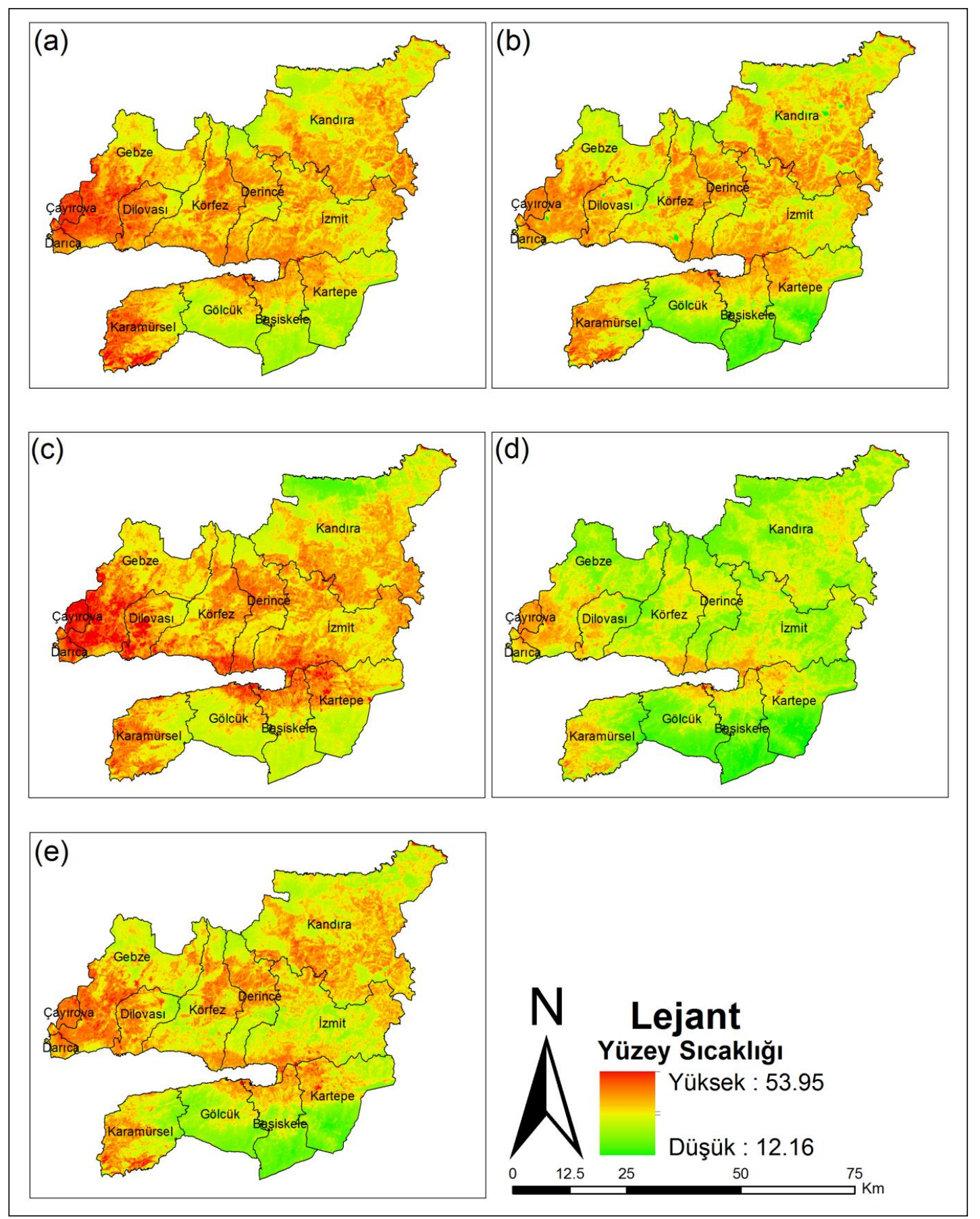

Şekil 4: Yıllara göre Kocaeli iline ait yer yüzey sıcaklığı haritaları; a) 2015, b) 2016, c) 2017, d) 2018, e) 2019 

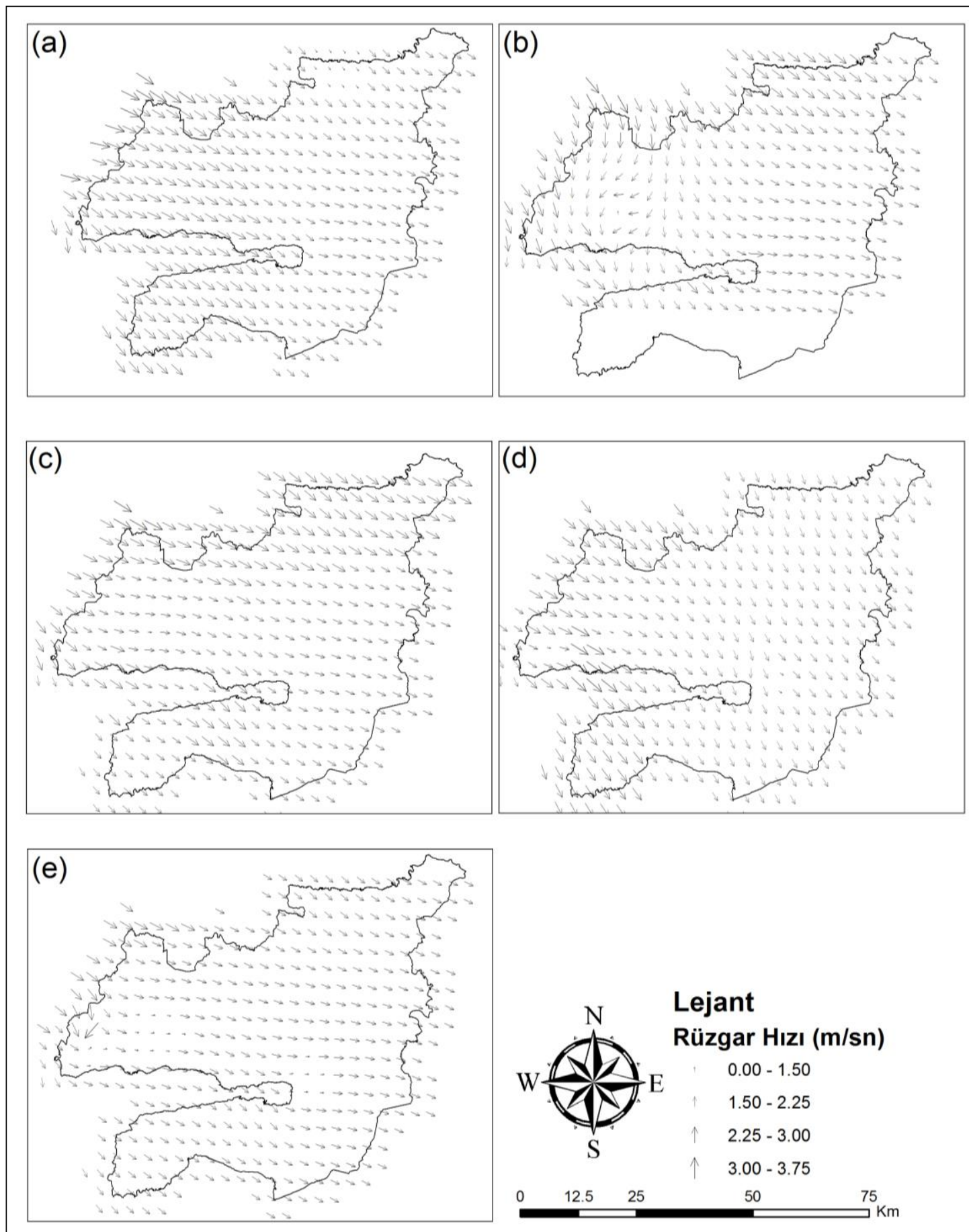

Şekil 5: Yıllara göre Kocaeli ili Temmuz ayına ait rüzgar hızı ve yönleri; a) 2015, b) 2016, c) 2017, d) 2018, e) 2019

Yıllara göre oluşturulan rüzgar haritaları incelendiğinde hakim rüzgar yönünün kuzeybatıdan güneydoğuya doğru ve genel rüzgar hızının ise genellikle 2.25 ile $3 \mathrm{~m} / \mathrm{sn}$ arasında olduğu görülmektedir. İlin batı kesimlerinde yani yer yüzey sıcaklığının yüksek olarak belirlendiği bölümlerde rüzgar hızının da yüksek olarak tespit edilmesi rüzgarların yer yüzey sıcaklığını azaltmaya etkisinin çok fazla olmadığının göstergesidir. Ayrıca bu durum ile ilgili olarak kent yerleşiminin etkileri, kentsel alanlardaki hava koridorları konuları araştırılması gereken konulardır. 2015 yılından itibaren İzmit Körfezi çevresindeki rüzgar hızı incelendiğinde beş yıllık periyot içerisinde düzenli bir azalmanın olduğu da görülmektedir.

İkinci olarak Bölüm 2.2'de bahsedilen indeks parametreleri ile yer yüzey sıcaklıkların arasındaki ilişki incelenmiştir. İndeks değerleri ile yer yüzey sıcaklığı arasındaki grafiklerin oluşturulmasında Excel programından yararlanılmıştır. Bunun içini Eşitlik (8) ve (9)'da gösterilen formüller yardımıyla çalışma alanına ait 2019 yılının SAVI ve NDBI değerleri belirlenmiştir. Daha sonra çalışma alanı içerisinde belirlenen rastgele 250 noktadan alınan yer yüzey sıcaklıkları ile SAVI ve NDBI değerleri arasındaki ilişki araştırılmıştır. 
$\mathrm{Bu} 250$ adet rastgele nokta il genelinin tümünü kapsayacak ve aşırı yoğunluk (birbirine yakın çok fazla nokta olmayacak) oluşturmayacak şekilde belirlenmiştir (Şekil 6). Şekil 7 ve 8'de SAVI ve NDBI değerleri ile yer yüzey sıcaklıkları arasındaki doğrusal korelasyon grafikleri gösterilmektedir. SAVI ve NDBI indeks değerleri ile yer yüzey sıcaklıkları arasında sırasıyla \%73 ve \%75'in üzerinde korelasyon bulunduğu tespit edilmiştir.

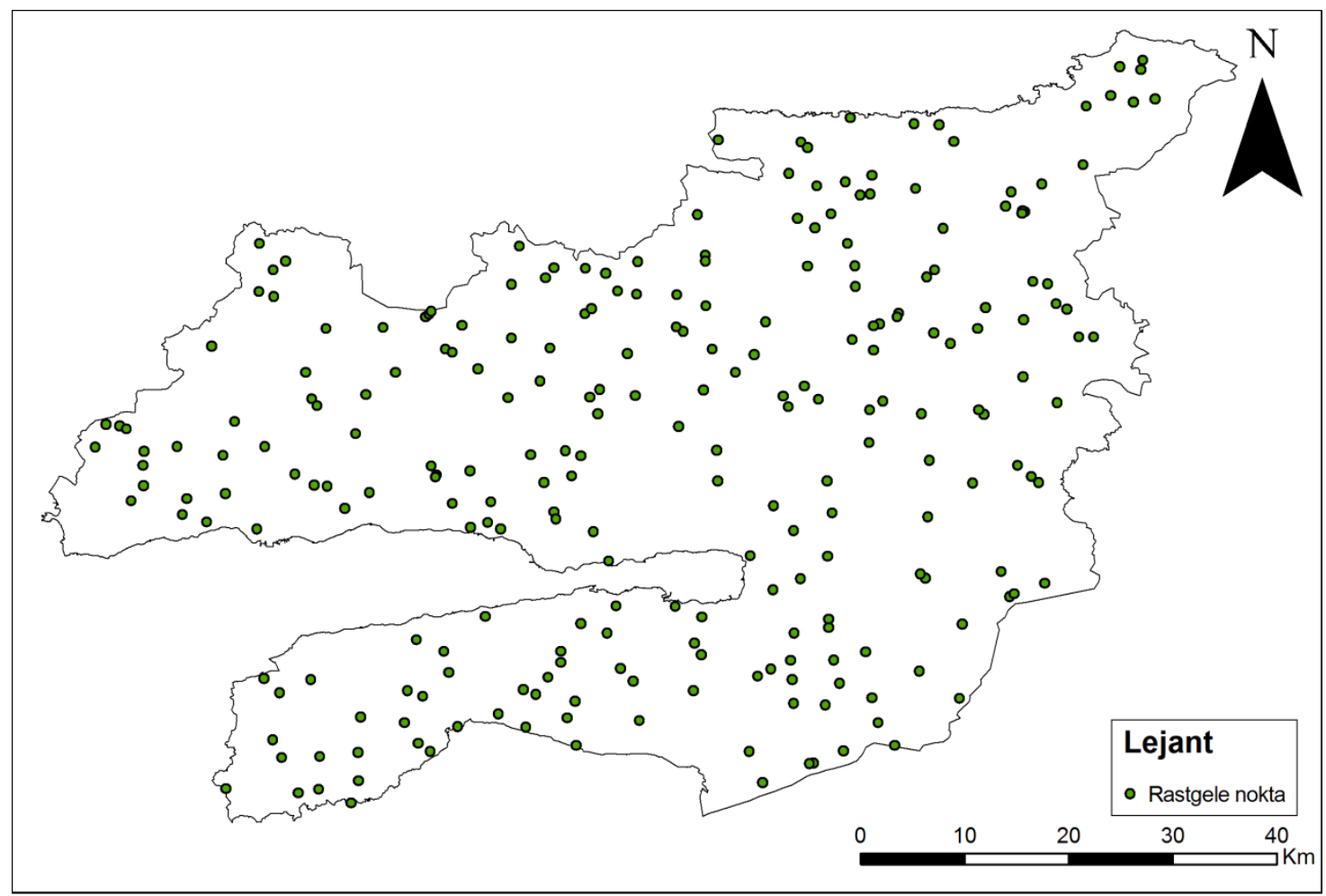

Şekil 6: Yer yüzey sıcaklıkları ile indeks değerlerinin karşılaştırılması için il genelinde seçilen rastgele noktalar

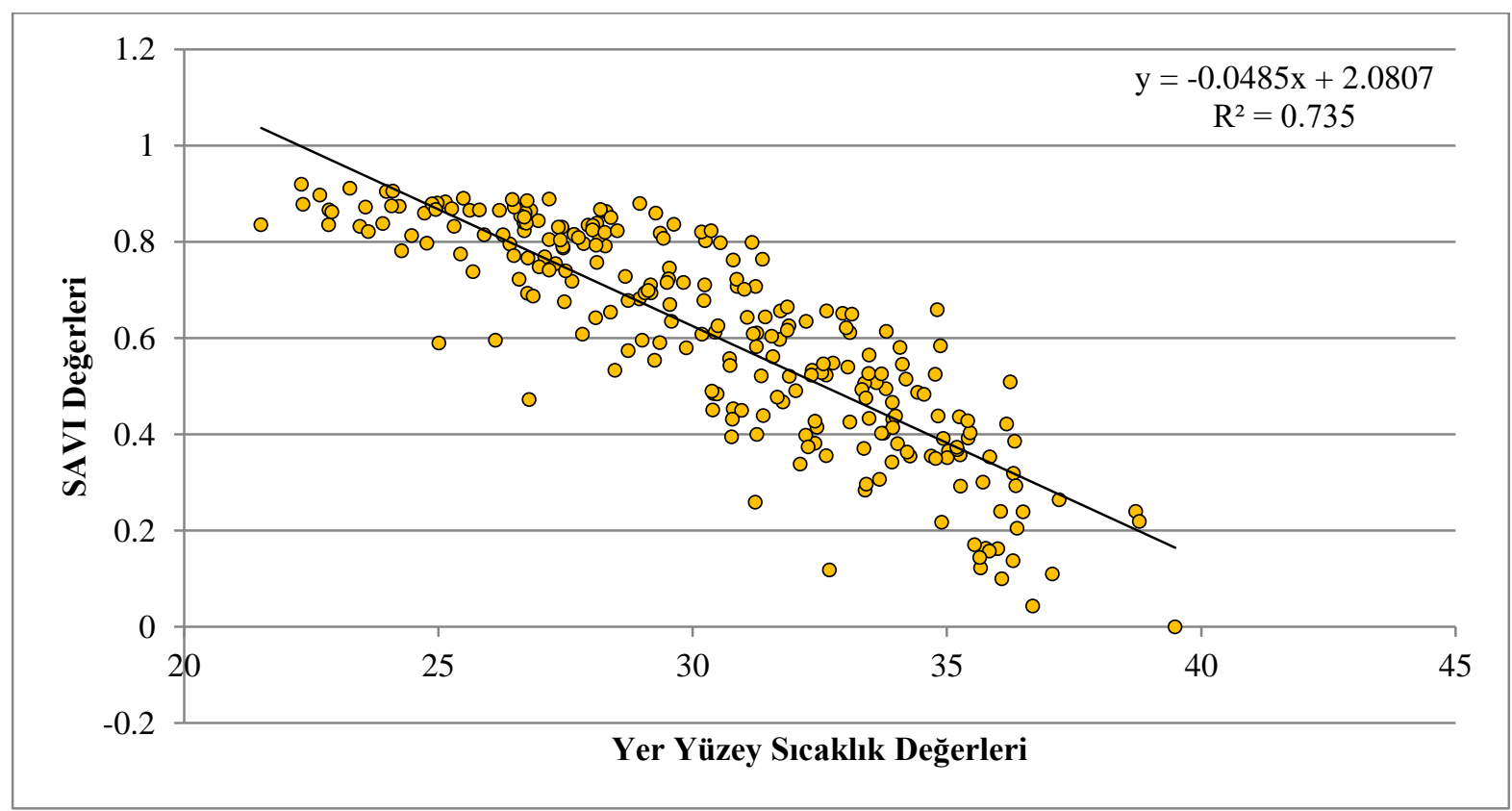

Şekil 7: Yer yüzey sıcaklıkları ile SAVI değerleri arasındaki ilişki

Yer yüzey sıcaklıkları ile SAVI arasındaki korelasyona bakıldığında doğrusal azalan bir ilişki belirlenmiştir. Doğrusal korelasyon katsayısı (R) 0.735 olarak bulunmuştur (Şekil 6). Elde edilmiş olan bu sonuç literatürde daha önce yapılmış olan Ma vd. (2008); Ergene (2016); Eswar vd. (2016); Ning vd. (2017); Macarof ve Birlıca (2018); Ning vd. (2018) gibi çalışmalar ile paralellik göstermiştir. 
SAVI değerinin azaldığı yani bitki örtüsünün azalarak açık toprak alanların arttığı bölgelerde yer yüzey sıcaklıklarının artış gösterdiği belirlenmiştir.

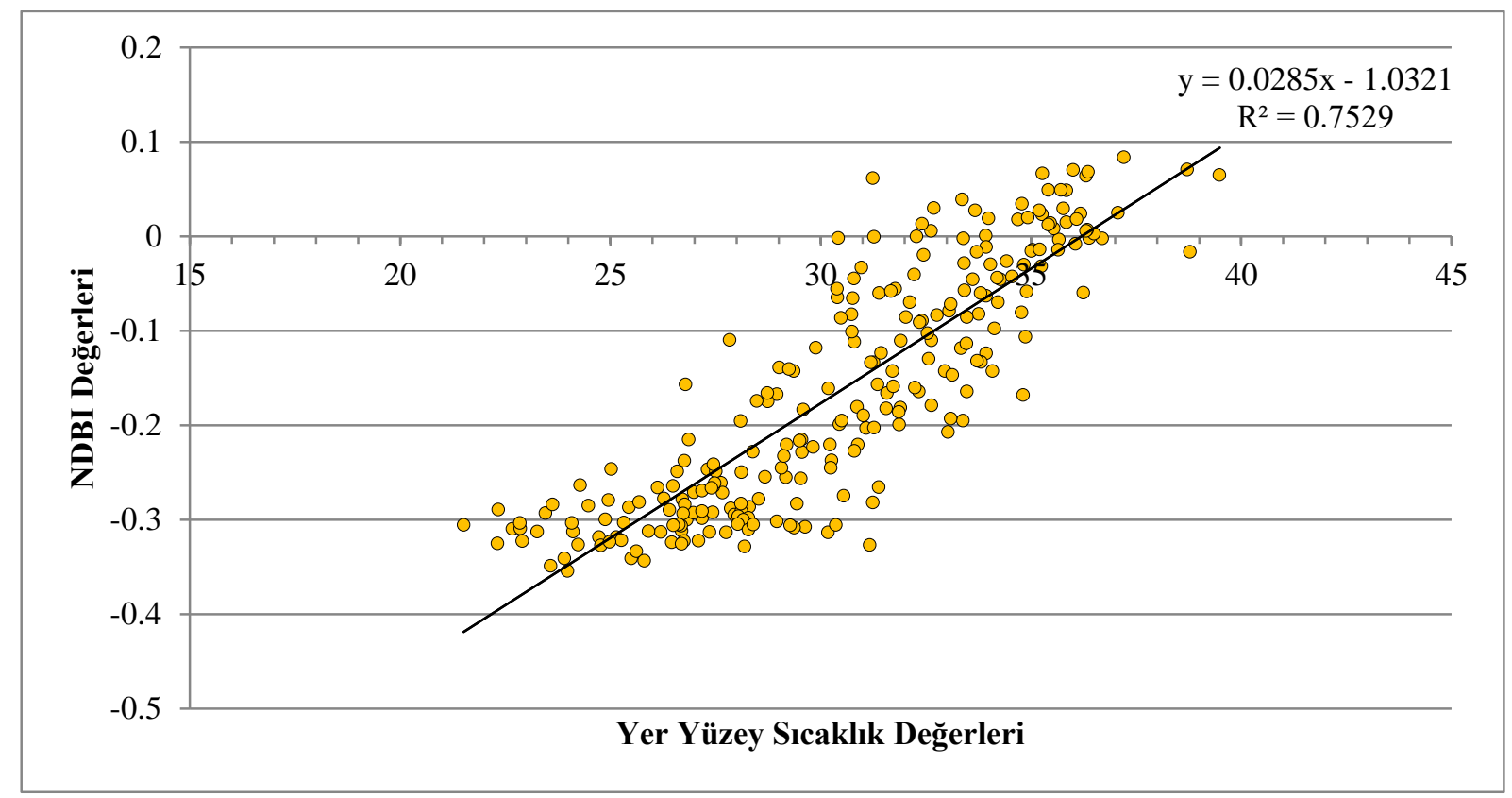

Şekil 8: Yer yüzey sıcaklıkları ile NDBı değerleri arasındaki ilişki

Yer yüzey sıcaklıkları ile NDBI arasındaki korelasyona bakıldığında doğrusal olarak artan bir ilişki tespit edilmiştir. Doğrusal korelasyon katsayısı (R) 0.7529 olarak bulunmuştur. NDBI değerleri ile yer yüzey sıcaklıkları arasında belirlenmiş olan yüksek korelasyon değeri literatürde bulunan Chen vd. (2006); Chen vd. (2013); Kumar ve Shekhar (2015); Kumar (2015); Ergene (2016); Malik vd. (2019) çalışmaları ile benzer sonuçların elde edildiğini göstermiştir. Kentsel ve sanayi alanlarında, yapılaşmanın yoğun olduğu bölgelerde -NDBI değerlerinin yüksek olduğu alanlarda- yer yüzey sıcaklıkları da artış göstererek yüksek değerlerde tespit edilmiştir.

\section{Sonuçlar ve Tartışma}

Çalışmada 2015 - 2019 yılları arasındaki 5 yıllık periyotta, Landsat 8 uydu görüntüsünün termal bandı (Band 10) kullanılarak Kocaeli il sınırları içerisindeki yer yüzey sıcaklıkları belirlenerek haritaları oluşturulmuştur. Çevre ve Şehircilik Bakanlığına ait olan Kocaeli ili ve çevresinde bulunan 18 adet Marmara Hava Kalitesi İzleme istasyonundan çalışma dönemi yıllarına ait rüzgar hızı ve yönü bilgileri elde edilerek rüzgar haritaları oluşturulmuş ve yer yüzey sıcaklıklarına yaptığı etki araştırılmıştır. Ayrıca uydu görüntülerinin spektral bandları kullanılarak üretilen SAVI ve NDBI değerleri ile yer yüzey sıcaklığı arasındaki ilişki -korelasyon- araştırılmıştır.

Elde edilen yer yüzey sıcaklıkları incelendiğinde yoğun sanayi tesislerine ve bununla birlikte hızla artış gösteren kentsel yerleşim alanlarına sahip olan Kocaeli’nin yer yüzey sıcaklığının beş yıllık periyot içerisinde ortalama $30.34{ }^{\circ} \mathrm{C}$ olduğu belirlenmiştir. İlin batısında bulunan yoğun sanayi tesislerine sahip Darıca, Çayırova, Gebze ve Dilovası ilçelerinin ve güneyinde bulunan Karamürsel ilçesindeki Samanlı Dağlarının eteklerinin beş yıllık periyot içerisinde yüksek yer yüzey sıcaklığına sahip olduğu tespit edilmiştir. Karamürsel ilçesindeki yüksek sıcaklığın sebebinin jeotermal aktivite olduğu düşünülmektedir.

Yer yüzeyi üzerindeki bitki örtüsü yoğunluğu arttıkça, sebep olduğu buharlaşma daha fazla olduğundan yer yüzey sıcaklığında azalma gözlenmektedir. Bu nedenle bitki örtüsü fazla ve yoğun olan yüzeylerde -bölgelerde- kaybedilen enerji miktarı fazla olduğundan dolayı soğumaya sebep olmaktadır (Gerçek ve Bayraktar 2014). Yer yüzey sıcaklığının bitki yoğunluğu ile ters, kentsel bina yoğunluğu ile doğru orantılı olduğu oluşturulan indeks değerleri ile belirlenmiştir. SAVI ve NDBI değerleri ile yer yüzey sıcaklıkları arasında hesaplanan korelasyon değerleri bunu doğrulamaktadır. Çalışma alanı içerisindeki yeşil alanların bulunduğu bölgelerde yer yüzey sıcaklıkları düşük, yapay ve toprak yüzeylerde ise yer yüzey sıcaklıkları yüksek olarak belirlenmiştir.

Taşdelen (2019)'in hazırladığı yüksek lisans tez çalışmasında Kocaeli ve Türkiye ölçeğinde YYS değerleri uydu görüntülerinden yararlanılarak belirlenmiştir. Kocaeli için YYS değerleri yüksekten düşük değere göre sanayi tesisleri, kent alanları, tarım ve yeşil alanlar ve su bölgeleri olarak sıralanmaktadır. Malik vd. (2019) NDBI ve NDVI ile YYS arasındaki ilişkiyi inceledikleri çalışmalarında kentsel yerleşimin yoğun olduğu bölgelerde (NDBI değerlerinin yüksek olduğu alanlarda) YYS ile yüksek korelasyon değerleri (\%95'in üzerinde) elde etmişlerdir. Ayrıca sağlıklı yeşil alanların YYS değerlerini azaltmada önemli bir rol oynadığının altını çizmişlerdir. 
Şekertekin ve Marangoz (2019) yerleşim alanları ve açık alanların, ormanlık ve bitki örtüsü alanlarına göre ortalama 4 ${ }^{\circ} \mathrm{C}$ daha yüksek YYS değerlerine sahip olduklarını belirlemişlerdir. Fils vd. (2018) YYS ile yerleşim alanı indeksi arasındaki ilişkiyi zamansal periyot içerisinde incelemişlerdir. 1986 y1lı uydu görüntülerinde düşük çıkan (0.35) korelasyon değeri, 2016 yılı görüntüsünde yüksek değerde tespit edilmiştir (0.77). Adeyeri vd. (2017) YYS ile indeks görüntüleri arasındaki korelasyonu inceledikleri çalışmalarında YYS ile SAVI ve NDBI indekslerini incelemişlerdir. Bu iki indeks ile YYS arasında sırasıyla ters ve doğrusal ilişki olduğu tespit edilmiştir. Erener ve Sarp (2018) Kocaeli’de bulunan sanayi alanlarının dağılımındaki değişimin yer yüzey sıcaklığına yaptığı etkiyi araştırmışlardır. 16 yıllık zaman periyodu için yer yüzey sıcaklığı değişim korelasyonu incelenmiştir. Balçık ve Ergene (2017) uzaktan algılama görüntüleri ile belirlenen yer yüzey sıcaklıkları ile doğal olmayan alanlar arasındaki ilişkiyi belirlemişlerdir. Yer yüzey sıcaklıkları ile çeşitli görüntü indekslerinin (NDVI, NDBI, SAVI) istatistiksel ilişkisi ortaya çıkarılmıştır. Erener ve Sarp (2017) kentleşmenin 1sı adası oluşumuna konumsal etkilerini uydu görüntüleri ile incelemişlerdir. Çalışmada bitkisel alanlar için NDVI, kentsel alanlar için ise NDBI değerleri ile YYS arasındaki korelasyon araştırılmıştır.

$\mathrm{Bu}$ çalışmada elde edilen sonuçlar yukarıda bahsedilen literatür çalışmaları ile paralellik göstermektedir. Literatür çalışmalarının çoğunluğunda sanayi ve kentsel alanlarda yüksek değerlerde çıkan YYS değerleri bu çalışmada da Kocaeli'nin batı bölgelerinde yüksek yoğunlukta bulunan sanayi bölgelerinde yüksek değerlerde tespit edilmiştir. Ayrıca yine literatürde yeşil alanlarda düşük olarak tespit edilmiş olan YYS değerleri yine bu çalışmada da düşük değerlerde belirlenmiştir. Literatür çalışmalarında görüntü indeksleri ile YYS arasında belirlenmiş olan korelasyon değerlerine benzer değerler bu çalışmada da belirlenmiştir. SAVI değerleri ile ters, NDBI değerleri ile doğrusal olarak tespit edilen korelasyon literatürdeki değerler ile benzerlik göstermektedir. Çalışmada rüzgar hızı ve yönü verileri ile oluşturulan haritalar ile YYS değerlerinin karşılaştırılması literatürde karşılaşılmayan analiz yöntemidir. Rüzgar verilerinin YYS'ye etki etmediği tespit edilmiş olsa bile literatürde bu iki verinin karşılaştırıldığı çalışmaya rastlanmamıştır.

Yapılan çalışmalar göstermiştir ki bitki örtüsü ile yüzey sıcaklıkları arasında negatif bir korelasyon bulunmaktadır. $\mathrm{Bu}$ nedenle şehir içerisinde veya çevresindeki yeşil alanların arttırılması yer yüzey sıcaklığının düşmesine sebep olacaktır. Yer yüzey sıcaklığının düşürülmesi için alınacak en önemli önlemlerden bir tanesi şehir içerisindeki yeşil alanların arttırılması olacaktır. Ayrıca kentsel bölgelerde ve sanayi tesisi alanlarında gerçekleştirilecek olan yeşil çatı uygulamaları, kentlerde oluşan yoğun ısı alanlarına çözüm olarak önerilebilir.

\section{Kaynaklar}

Adeyeri O. E., Akinsanola A. A., Ishola K. A., (2017), Investigating surface urban heat island characteristics over Abuja, Nigeria: Relationship between land surface temperature and multiple vegetation indices, Remote Sensing Applications: Society and Environment, 7, 57-68.

Anandababu D., Puruhothaman B. M., Babu S. S., (2018), Estimation of land surface temperature using landsat 8 data, International Journal of Advance Research, Ideas And innovations in Technology, 4(2), 177- 186.

Avdan U., Javanovska G., (2016), Algorithm for automated mapping of land surface temperature using landsat 8 satellite data, Journal of Sensors, 2016, 1-8.

Balçık F. B., Ergene E. M., (2017), Yer yüzey sıcaklı̆̆ının termal uzaktan algılama verileri ile belirlenmesi: İstanbul örneği, Türkiye Ulusal Fotogrametri ve Uzaktan Algılama Birliği 9. Teknik Sempozyumu Bildiri Özetleri Kitabı içinde (Turgut B. vd., Ed), Afyonkarahisar, Türkiye, ss 21.

Chen X. L., Zhao H. M., Li P. X., Yin Z. Y., (2006), Remote sensing image-based analysis of the relationship between urban heat island and land use/cover changes, Remote Sensing of Environment, 104(2), 133-146.

Chen L., Li M., Huang F., Xu S., (2013), Relationship of LST to NDBI and NDVI in Wuhan city based on Landsat ETM+ image, 6th International Congress on Image and Signal Processing (CISP) Volume II içinde, Hangzhou, China, ss 840-845.

Erener A., Sarp G., (2017), Kentleşmenin ısı adaları oluşumu üzerine etkisinin uzaktan algılama teknolojileri ile değerlendirilmesi, I. Uluslararası Bilimsel ve Mesleki Çalışmalar Kongresi Özet Kitabı içinde, Nevşehir, Türkiye, ss 229-230.

Erener A., Sarp G., (2018), Spatiotemporal distribution of industrial regions and impact on LST in the case of Kocaeli, FIG Congress 2018 Proceedings, İstanbul, Türkiye, https://www.fig.net/resources/proceedings/fig_proceedings/fig2018/papers/ts07c/ TS07C_erener_sarp_9639.pdf, [Erişim 08 Ekim 2019].

Ergene E. M., (2016), Landsat 8 uydu görüntüsü kullanılarak yeryüzü sıcaklıklarının uzaktan algllama tekniği ile belirlenmesi: İstanbul örneği, Yüksek Lisans Tezi, İstanbul Teknik Üniversitesi, Fen Bilimleri Enstitüsü, İstanbul, Türkiye.

Eswar R., Sekhar M., Bhattacharya B. K., (2016), Disaggregation of lst over india: comperative analysis of different vegetation indices, International Journal of Remote Sensing, 37(5), 1035-1054.

Fils S. C. N., Mimba M. E., Dzana J. G., Etouna J., Mounoumeck P. V., Hakdaoui M., (2018), TM/ETM+/LDCM images for studying land surface temperature (lst) interplay with impervious surface changes over time within the douala metropolis, Cameron, Journal of the Indian Society of Remote Sensing, 46, 131-143.

Gerçek D., Bayraktar N. T., (2014), Kentsel ısı adası etkisinin uzaktan algılama ile tespiti ve değerlendirilmesi: İzmit kenti örneği, 5. Uzaktan Algilama-CBS Sempozyumu, 14-17 Ekim, İstanbul, Türkiye. http://www.uzalcbs2014.sempozyumu.net/bildiriler.php, [Erişim 08 Ekim 2019].

Jeevalakshmi D., Reddy S. N., Manikiam B., (2017), Land surface temperature retrieval from landsat data using emissivity estimation, International Journal of Applied Engineering Research, 12(20), 9679-9687.

Kumar D., (2015), Remote sensing based vegetation indices analysis to improve water resources management in urban environment, Aquatic Procedia, 4, 1374-1380. 
Kumar D. Shekhar S., (2015), Statistical analysis of land surface temperature-vegetation indexes relationship through thermal remote sensing, Ecotoxicology and Environmental Safety, 121(1), 39-44.

Li Z. L., Tang B. H., Wu H., Ren H., Yan G., Wan Z., Trigo I. F., Sobrino J. A., (2013), Satellite-derived land surface temperature: current status and perspectives, Remote Sensing of Environment, 131, 14-37.

Ma W., Chen Y. H., Zhou J., Gong A., (2008), Quantitative analysis of land surface temperature vegetation indexes relationship based on remote sensing, The International Archives of the Photogrammetry, Remote Sensing and Spatial Information Sciences Vol. XXXVII Part 6b, 3-11 July, Beijing, China. https://www.isprs.org/proceedings/XXXVII/congress/6b_pdf/43.pdf, [Erişim 04 Ekim 2019].

Macarof P., Birlica C. I., (2018), Investigating land surface temperature and vegetation indeces changes using landsat data: a case study of laşi county, Georeview, 28(1), 1-9.

Malik M. S., Shukla J. P., Mishra S., (2019), Relationship of LST, NDBI and NDVI using Landsat-8 data in Kandaihimmat Watershed, Hoshangabad, India, Indian Journal of Geo Marine Sciences, 48(1), 25-31.

Ndossi M. I., Avdan U., (2016), Açık kaynak kod teknoloji kullanılarak yer yüzey sıcaklı̆̆ının belirlenmesinde yeni bir eklentinin geliştirilmesi, 6.Uzaktan Algılma-CBS Sempozyumu Bildiriler Kitabı içinde, (Maktav D., Berberoğlu S., Ed.), Adana, Türkiye, ss $1135-1141$.

Ning J., Gao Z., Chen M., (2017), Analysis of relationships between ndvı and land surface temperature in coastal area, Proc. SPIE Remote Sensing and Modelling of Ecosystems for Sustainability XIV içinde, (Gao W., Chang N.B.,Wang J., Ed.), San Diego, California, USA.

Ning J., Gao Z., Meng R., Xu F., Gao M., (2018), Analysis of relationship between land surface temperature and land use changes in the yellow river delta, Frontiers Earth Science, 12(2), 444-456.

Oğuz H., (2016), Automated land surface temperature retrieval from landsat 8 satellite imagery: a case study of KahramanmaraşTurkey, Environmental Sustainability and Landscape Management içinde, (Efe R., Cürebal İ., Gad A., Toth B., Ed.), St. Kliment Ohridski University Press, Sofia, 598-604.

Oke T. R., (1982), The energetic basis of the urban heat island, Quarterly Journal of the Royal Meteorological Society, 108(455), 124.

Öztürk M. Z., Çetinkaya G., Aydın S., (2017), Köppen-geiger iklim sinıflandırmasına göre Türkiye’nin iklim tipleri, İstanbul Üniversitesi Coğrafya Dergisi, 35, 17-27.

Parker A. K., Warner D. A., (1973), Method and apparatus for making a temperature-referenced color strip map of thermal variations, In.: US Patent 3, 752, 915.

Prata A. J., Caselles C. C., Sobrino J. A., Ottle C., (2009), Thermal remote sensing of land surface temperature from satellites: current status and future prospects, Remote Sensing Reviews, 12, 175-224.

Sobrino J. A., Jimenez-Munoz J. C., Paolini L., (2004), Land surface temperature retrieval from Landsat TM 5, Remote Sensing of Environment, 90(4), 434-440.

Sobrino J.A., Raissouni N., (2000), Toward remote sensing methods for land cover dynamic monitoring: application to Morocco, International Journal of Remote Sensing, 21, 353-66.

Şekertekin A. İ., Marangoz A. M., (2019), Zonguldak metropolitan alanındaki arazi kullanımı arazi örtüsünün yer yüzey sıcaklı̆̆ına etkisi, Geomatik Dergisi, 4(2), 101-111.

Şensoy S., Shahin L., Yılmaz E., Türkoğlu N., Çiçek İ., Darende V., Yazıcı B., (2017), Antalya yüzey ısı adası özelliklerinin uydu verileri ile analizi, III. Meteorolojik Uzaktan Algılama Sempozyumu, 16-19 Ekim, Antalya, Türkiye. https://www.mgm.gov.tr/FILES/iklim/yayinlar/2017/17.pdf, [Erişim 08 Ekim 2019].

Taşdelen Ö., (2019), Yer yüzey sicaklık haritalarının yerel ve ülke ölçeğinde zamansal ve mekansal olarak uzaktan algılama ile tespiti, Yüksek Lisans Tezi, Kocaeli Üniversitesi, Fen Bilimleri Enstitüsü, Kocaeli, Türkiye.

URL-1, (2017), Kocaeli'nin sosyo-ekonomik yapısl, https://www.kocaeli.bel.tr/tr/main/pages/sosyo-ekonomik-yapi/100, [Erişim 07 Ekim 2019].

URL-2, (2019), TÜIK temel istatistikler, http://www.tuik.gov.tr/UstMenu.do?metod=temelist, [Erişim 07 Ekim 2019].

URL-3, (2019), Meteoroloji Genel Müdürlüğ̈̈ Resmi İstatistikler, https://www.mgm.gov.tr/veridegerlendirme/il-ve-ilceleristatistik.aspx?k=A\&m=KOCAELI, [Erişim 07 Ekim 2019].

USGS (2019), Landsat 8 (L8) data users handbook, Ed.Zanter, K., EROS Sioux Falls, South Dakota, USA, 114ss.

Weng Q., Lu D., Schubring J., (2004), Estimation of land surface temperature-vegetation abundance relationship for urban heat island studies, Remote Sensing of Environment, 89(4), 467-483.

Yıldız A., Bağcı M., Başaran C., Çonkar F. E., Ayday C., (2017), Landsat 8 uydu verilerinin jeotermal saha araştırmalarında kullanılması: Gazlıgöl (Afyonkarahisar) çalışması, Afyon Kocatepe Üniversitesi Fen ve Mühendislik Bilimleri Dergisi, 17, 277284.

Y1lmaz E., (2015), Landsat görüntüleri ile Adana yüzey ısı adası, Coğrafi Bilimler Dergisi, 13(2), 115-138.

Yüksel Ü. D., Y1lmaz O., (2008), Ankara kentinde kentsel ısı adası etkisinin yaz aylarında uzaktan algılama ve meteorolojik gözlemlere dayalı olarak saptanması ve değerlendirilmesi, Gazi Üniversitesi Mühendislik Mimarlık Fakültesi Dergisi, 23(4), 937-952.

Zhang J., Wang Y., Li Y., (2006), A C++ program for retrieving land surface temperature from the data of Landsat TM/ETM+ band 6, Computers \& Geosciences, 32(1), 796-805. 